\title{
CONSTITUTIONALITY OF THE ECKHARDT OPEN BEACHES BILL
}

\author{
CHARLES L. BLACK, JR.*
}

One of the persisting and pervasive themes in the life of Mr. Justice Douglas has been his concern with preserving and holding open to public enjoyment the natural world around us. It is fitting, therefore, that this issue of the Review should contain a discussion of the constitutionality of the Open Beaches bill, ${ }^{1}$ which is now being pressed by Congressman Eckhardt of Texas, with numerous co-sponsors, and which has recently been the subject of hearings by the House Committee on Merchant Marine and Fisheries. ${ }^{2}$ This Article follows closely along the lines of my testimony before the House Committee on October 26, $1973 .^{3}$

\section{Introduction: Purpose and Strategy}

The bill sets out to counter the enclosure movement, which threatens drastically to cut down the number and quality of beaches available to the public. Section 202 expresses the national interest in maintenance of the "free and unrestricted right" of the American public to use the beaches of the United States, insofar as this use is consistent with the rights of littoral owners; $;^{4}$ and section 203 makes obstruction of this right unlawful. ${ }^{5}$ Section 204 empowers the federal courts to hear and determine suits brought by the United States for establishing and protecting this public right, and for other closely connected purposes, including condemnation where necessary or de-

* Henry R. Luce Professor of Jurisprudence, Yale University. B.A. 1935, M.A. 1938, University of Texas; LL.B. 1943, Yale University.

1. H.R. 10394, 93d Cong., 1st Sess. (1973). For a discussion of the history and policy behind this bill see Eckhardt, $A$ Rational National Policy on Public Use of the Beaches, 24 SyRACUSE L. REv. 967 (1973).

2. Hearings on H.R. 10394 Before the Subcomm. on Fisheries and Wildlife Conservation and the Environment of the House Comm. on Merchant Marine and Fisheries, 93d Cong., 1st Sess. (1973).

3. Id. at 119-141.

4. Section 202 provides:

By reason of their traditional use as a thoroughfare and haven for fishermen and sea ventures, the necessity for them to be free and open in connection with shipping, navigation, salvage, and rescue operations, as well as recreation, Congress declares and affirms that the beaches of the United States are inpressed with a national interest and that the public shall have free and unrestricted right to use them as a common to the full extent that such public right may be extended consistent with such property rights of littoral landowners as may be protected absolutely by the Constitution. It is the declared intention of Congress to exercise the full reach of its constitutional power over the subject.

H.R. 10394, 93d Cong., 1st Sess. § 202 (1973).

5. Section 203 provides:

No person shall create, erect, maintain, or construct any obstruction, barrier, or restraint of any nature which interferes with the free and unrestricted right of the public, individually and collectively, to enter, leave, cross, or use as a common the public beaches.

Id. $\S 203$. 
sired. $^{6}$ Additional procedures, including modes of state-federal cooperation, are authorized in subsequent sections. ${ }^{7}$

Thus, the dominant strategy of the bill is very simple. It accepts, as given, the substantive state-law position regarding beach ownership and public rights over beaches, but it "declares and affirms" that the beaches of America shall be open for public recreational use wherever state law does not preclude this result. It then makes any obstruction of public right, other than in conformity to state law, unlawful as a matter of federal law. And it goes on to provide a machinery of federal jurisdiction and of federally financed litigation to vindicate the rights so declared and protected. ${ }^{8}$ The basic theory is that of a federal law reaching to touch (but not to disturb) state substantive law, coupled with an appropriate remedial apparatus to uphold the national interest.

This strategy rests in large part on the suppositions, first, that state law, as a matter of substance, gives a great deal of protection to public access and use $^{8}$ and, secondly, that the fifth amendment ${ }^{10}$ would in any case restrain Congress from decreeing public access to beaches which state law makes private-except, of course, by condemnation, which is provided for separately. ${ }^{11}$ The principal national contribution is therefore to be the provision of remedial machinery and litigation resources for procuring judicial declaration and protection of judicially ascertained public rights. This is of crucial importance in this field, since private encroachments on public beaches may ripen into prescriptive right, unless timely legal action is taken. ${ }^{12}$

\section{Constitutionality}

It might be thought that the constitutionality of such a bill is obvious. It can hardly be questioned that the whole American public has a substantial or even vital interest in access to adequate marine beach facilities and, with good

\section{Section 204 provides:}

(a) An action shall be cognizable in the district courts of the United States without reference to jurisdictional amount, at the instance of the Attorney General or a United States district attorney to:

(1) establish and protect the public right to beaches,

(2) determine the existing status of title, ownership, and control, and

(3) condemn such easements as niay reasonable be necessary to accomplish the purposes of this title.

(b) Actions brought under the authority of this section may be for injunctive, Id. $\$ 204$. declaratory, or other suitable relief.

7. See id. $\S \$ 206-10$.

8. See id. \& 204, quoted in note 6 supra.

9. See Eckhardt, supra note 1, at 974-80. "The [state] cases all culminate in protection of a public right." Id. at 980 . See generally Degnan, Public Rights in Ocean Beaches: A Theory of Prescription, 24 SYRAcuSE L. Rev. 935 (1973); Note, Public Access to Beaches, 22 Stan. L. Rev. 564 (1970).

10. U.S. Const. amend. V: "nor shall private property be taken for public use, without just compensation."

11. See H.R. 10394, 93d Cong., 1st Sess. \& 204(a) (3) (1973), quoted in note 6 supra.

12. See Note, supra note 9 , at 586 . 
warrant, we have grown accustomed to assuming that any congressional step that implements an authentic and massive national interest will find justification under the Constitution, as long as none of the expressly prohibitory material in that document is implicated. Still, it cannot be amiss to spell out the constitutional grounds on which this bill rests.

\section{A. Substantive Federal Interests}

Let us first consider where the unquestioned national substantive interest in free public access to beaches may fit into the categories of the Constitution.

To begin with, there is the familiar ground of the commerce clause, ${ }^{13}$ which we tend to use for everything. The main point to make here is that the commerce-clause ground for upholding this bill is not a mere pretext, as it is, for example, with regard to the Mann Act, ${ }^{14}$ the Lindberg Law, ${ }^{15}$ or the Stolen Automobiles Act. ${ }^{16}$ It is the visible fact that interstate movement of goods and people is massively affected by the availability and location of usable beaches. Trains and airplanes travel from Duluth and Salt Lake City to Florida, full throughout the winter. The Martha's Vineyard ferry, through the whole summer, carries New York and even Illinois license plates. Commodities in economically significant quantity move toward the great ocean and Gulf recreational areas. A national concern in the openness and adequacy of the beaches that are the center of all this activity could easily be rested on the commerce clause alone.

But I suspect that, as a matter of rhetoric though not of law, we may have overworked the commerce clause. The recital of its very obvious connection with beach availability has the sound of a lesson learned by rote-a valid lesson, but a trite one nonetheless. I would prefer, therefore, to pass on to what I may call a more fundamental and more apt constitutional ground for upholding this bill. Briefly but sufficiently, this is that the "public," for purposes of the "public" easements and "public" dedications that are the technical forms under which beaches are lawfully open, ${ }^{17}$ is the "public," or the people, of the United States.

Here a word of explanation may be helpful. To say that a beach is, as a matter of law, "public," is usually to say that there exists with respect to it either a public easement or a public dedication. The existence, the modes of coming into existence and the exact contours of these are matters of state law, with some variance from state to state. The state-law issues have just lately

13. U.S. Const. art. I, \& 8 .

14. 18 U.S.C. $\$ \S 2421-24$ (1970).

15. Id. §§ $1201-02$.

16. $I d$. $\$ \S 2312-13$.

17. See the authorities collected in note 9 supra. There are more variations than those to which I have referred, but all require the identification of some "public" as the "public" enjoying the right to use the beach-a right that it would be a shame to leave behind without giving its ancient name, jus spationdi. 
been well and fully treated, ${ }^{18}$ and it is not the task here to treat them again. My only point now is that each of these concepts-"public" easement and "public" dedication-requires the identification of the relevant "public," and that both in fact and in law the relevant public is the whole American people.

I first say "in fact" because both these two legal phenomena commonly arise through the fact of long and immemorial usage by "the public;" and it seems next to impossible that this using "public," as to any particular beach, will not have included, through the decades and even centuries, people from other states than the one in which the beach is situate. If it enacts the Eckhardt bill, Congress in effect will have made this nearness to impossibility into a conclusive presumption-not a conclusive presumption that any particular beach is "public,"19 but a conclusive presumption that, if it is generally "public," the "public" is the American people. It is hard to see how such a presumption could harm anyone, or "take" anyone's "property," and equally hard to imagine any significant case in which it would not be in accord with the facts.

I say, secondly, "in law," because if (as seems highly unlikely) the statutory or common law of any state were to make its beaches "public" to its own residents but not to those of other states, that law would, I submit, violate the federal Constitution. As to citizens of other states, I should suppose it would rather plainly violate the first clause of article IV, section 2 , wherein it is decreed that "The Citizens of each State shall be entitled to all Privileges and Immunities of Citizens in the several States." It is hard to think of any privilege this clause would cover if not the "privileges" of bathing in the ocean and strolling on the shore. I think, moreover (and here I consciously bridge over a good deal of what seems to me futile word-shuffling) that a "privilege" granted by article IV may also be, at least in such a case as this, a "privilege" protected at the same time by the first section of the fourteenth amendment. 20

Some people shy at the invocation of these "privileges" because they are textually linked to "citizenship." Without broaching a general theory on this, I would say that if any state sought to restrict its public beaches to American "citizens" alone, solid Supreme Court precedent may be relied upon, a fortiori, to invalidate such a senseless discrimination. ${ }^{21}$ The true position seems to me to be that, where one part of the Constitution guarantees something to citizens, and where not the suspicion of a rational ground exists for distinguishing be-

18. See note 9 supra.

19. For the rebuttable presumption on this see section 205 , discussed in text accompanying note 34 infra.

20. U.S. Const. amend. XIV, § 1: "No State shall make or enforce any law which shall abridge the privileges or immunities of citizens of the United States . ..."

21. See Takahashi v. Fish and Game Comm'n, 334 U.S. 410 (1948); Truax v. Reich, 239 U.S. 33 (1915). 
tween citizens and aliens, then both of the due process clauses ${ }^{22}$ guarantee the same thing to aliens..$^{23}$

But, though I regard these textual bases as quite firm, I would prefer, at last, to put the whole matter on the Crandall v. Nevada ${ }^{24}$ ground, broadly surveyed. We are a nation; nothing can be lawful that is inconsistent with full nationhood. We would be a mere caricature of a nation if it were thinkable that a part of the national shoreline could, for example, be "public" for Virginians but, under Virginia law, closed to everybody else.

Let me strongly emphasize, however, that I am not talking against or about any real state law, whether statutory or common. No state, as far as I know, has ever uttered such a ridiculous law. On the contrary, most if not all the littoral states advertise for inlanders to come bathe in water and sun. What I am actually putting forward is a theory of national interest in the subject matter-a national interest that can serve not only for the imaginary invalidations of improbable state laws, but also for affirmatively supporting the constitutionality of congressional intervention.

\section{B. Mode of Federal Effectuation}

Now if these constitutional bases are solid, or if any of them is solid, the only remaining question is whether the bill is vulnerable to constitutional objections based upon its mode of going to work to vindicate the national interest. That mode of going to work consists, as we have seen, in providing a federal forum for determining and declaring the legal status of marine beaches, while the substantive questions are in some sense referred ultimately to state law. The objection might be that such an approach is impermissible, on the ground that it brings into the federal judicial jurisdiction cases which "arise under" state law rather than under federal law, in disregard of the implied command of article III of the Constitution. ${ }^{25}$

If this question arose nakedly in regard to this bill, I would have no hesitation in concluding that the step of bringing litigation into the federal courts, while deferring to state substantive law, is entirely proper and entirely satisfies the "arising under" clause when, as here, the subject matter is one over which Congress has general power under the Constitution. The matter has never been better put than, long ago, by my colleagues, Bickel and Wellington:

It would be most regrettable if a federal constitution forbade the general government to exercise its regulatory powers in this forebearing, sanguine, and initially perhaps experimental manner which

22. U.S. Const. amends. V, XIV, § 1. (1969).

23. See C. Black, Structure and Relationship in Constitutional Law 64

24. 73 U.S. (6 Wall.) 35 (1868).

25. U.S. Const. art. III, § 2. 
turns to account the genius of a federal system. It would be regrettable for Congress to be forced instead to exert its authority to the full in order to be able to employ it at all. Is this the effect of article III of our Constitution? The answer would be yes if it were true that to allow for federal-question jurisdiction in cases arising only under a jurisdictional statute is in effect to eliminate the "arising-under" clause of the Constitution as a limitation on federal jurisdiction. It is inadmissible to construe article III so as to provide generally for the sort of jurisdiction which the framers provided for in cases of diversity of citizenship only. But there is no occasion here to obliterate the distinction between the diversity of citizenship and the "arising-under" clauses of article III. The "arising-under" clause, if our view is accepted, can still come into play only when one of the enumerated heads of legislative powers enables Congress to act. If a considerable slice of state law can thus be brought into federal forums regardless of the citizenship of the parties, although in the conditions of earlier times that would have been possible only in the diversity jurisdiction, the reason is simply the general expansion of the area of federal interest and competence. It is no more shocking to observe this development in article III than in the commerce clause and indeed, as we have suggested, permitting it to take place in article III conduces to an abatement of the inroads of this expansion's other manifestations on the federal system. ${ }^{26}$

I would only add that the matter covered by the Eckhardt bill is especially suited for treatment in this manner. There is, as I have shown above, a constitutionally-based national interest, assertible by Congress, in seeing that all public beaches remain public. No change in substantive law is now sought; all that is wanted is just exactly an expeditious pressing of litigation to preserve what the American public already has under the applicable substantive law. The step of providing the means for conducting such litigation is tailored to fit the felt need; it is a step precisely instrumental to the national interest. How could there be anything wrong in Congress' providing a means so apt to this national need, coupled with the maximum deference to state substantive law?

But the question under this bill need not remain thus at large. Several more well-travelled routes lead to a recognition of the constitutional validity of the means this bill chooses.

First and most obviously, this bill does set up federal substantive law, even though this federal law is deferent to state law, for section 202 says that "with the full reach of its constitutional power" Congress "declares and affirms" that the beaches of the United States shall be open, saving only "such property rights of littoral landowners as may be protected absolutely by the Constitution."27 This provision is itself federal law, reaching out, it is true, to meet such state law as may create property rights absolutely protected by

26. Bickel \& Wellington, Legislative Purpose and the Judicial Process: The Lincoln Mills Case, 71 HARv. L. REv. 1, 20-21 (1957).

27. H.R. 10394, 93d Cong., 1st Sess. 8202 (1973), quoted in note 4 supra. 
the federal constitution, but federal law up to that line-a line, incidentally, defined not by state law alone, but by state law in coaction with the federal Constitution. Lest there be any doubt about this, section 203 goes on to make affirmatively unlawful, now very clearly as a matter of federal law, any obstruction of the public rights recognized and given a federal character by section 202.28 Litigation brought under section 204(a) and (b) is brought to uphold the very rights created by sections 202 and 203, and therefore quite directly "arises under" federal law. ${ }^{28}$

Secondly, if the relevant "public," with respect to the easement and dedications that make beaches "public," is (as I have argned above) ${ }^{30}$ the whole American people, then the United States, as parens patriae, plainly may sue in its own courts to vindicate this right of its citizens and of the other residents it has admitted. ${ }^{31}$ A closely related theory would say that, if the obstruction of a public beach is a public nuisance or any other wrong against the public, and if the "public" meant is the whole American people, then the national government, again quite plainly, may sue to prevent the obstruction. Under both these variations of this approach (and perhaps even under the federal substantive law theory stated in the paragraph just before this), it is true not only that the suit "arises under" federal law (here, federal constitutional law) but also that the United States is properly a party, bringing into play another article III empowerment. ${ }^{32}$

Thirdly, suits under section 204(a) (1) and (2) are ancillary and sometimes pendent to federal proceedings to condemn a public easement of enjoyment in those beaches over which such easement does not already exist. ${ }^{33}$ There are two ways in which this works. As to any particular beach, common sense advises that the first thing necessary to know, before spending the taxpayers' money to get the beach for public use, is whether the public already has the right to use it under the applicable law; a judicial proceeding is the only way to get a binding answer to this question. As to beaches in general, along any stretch of shoreline, the only sensible way to find out how much beach you need to condemn for public use is to be advised-with the degree of certainty afforded only by judicial proceedings-how many and what sort of beaches along that same stretch of shore are already public under law. Rational condemnation proceedings are therefore quite impossible, in the particular case or as to a whole region, without the authority to bring proceedings to ascertain and to vindicate the public right as it already stands

28. Id. § 203, quoted in note 5 supra.

29. Id. \$\$ 204(a), (b), quoted in note 6 supra.

30. See notes 17-20 supra and accompanying text.

31. Cf. Massachusetts v. Mellon, 262 U.S. 447, 486 (1923).

32. Federal jurisdiction extends, inter alia, "to Controversies to which the United States shall be a Party." U.S. Const. art. III, § 2.

33. H.R. 10394, 93d Cong., 1st Sess. \$ 204(a) (3) (1973), quoted in note 6 supra. 
prior to condemnation. To all such proceedings, the United States is the one invariable and indispensable plaintiff, and all such proceedings "arise under" federal law, so that article III doubly covers the situation.

In sum, then, under any of the theories discussed above, the bill's mode of effectuating the national interest seems to me undoubtedly constitutional.

\section{Presumption of Public Access}

There remains for consideration the validity of section 205, which provides:

The following rules applicable to considering the evidence shall be applicable in all cases brought under section 204 of this title:

(1) a showing that the area is a beach shall be prima facie evidence that the title of the littoral owner does not include the right to prevent the public from using the area as a common;

(2) a showing that the area is a beach shall be prima facie evidence that there has been imposed upon the beach a prescriptive right to use it as a common. ${ }^{84}$

After a full roundup of the cases, a leading modern authority calls it "extremely unlikely that there are now serious constitutional limits on the effect that may be given to presumptions in civil cases." 85 Nevertheless, it is well to point out that the elements rationally supporting a presumption such as that stated in section 205 are present. It is unquestionable that the littoral owner, claiming the right to obstruct a beach and to make it his own, is far better positioned than the public can be with regard to access to the evidence concerning prior use. The question whether, on the whole, the beaches of America have been used by the public from time immemorial is a question about general custom and social history suitable for congressional determination. If Congress, in effect, makes that determination by enacting section 205, then no court would failt it unless it were clearly wrong. It seems very unlikely that evidence could be produced to show generally that the custom as to our beaches has traditionally been one of private right and exclusion. ${ }^{30}$

As to this section 205 presumption, it need only be said that the burden of going forward with evidence and the burden of persuasion must rest somewhere. A judgment by Congress that they ought to rest on the party claiming a right to exclude the public from a beach is reasonable, in the constitutional sense, and it seems quite unlikely that any court would invalidate it. ${ }^{87}$ The

34. Id. § 205.

35. C. MCCORMACK, HaNdBooK of the LAw of Evidence $\S 345$ (2d ed. 1972).

36. One of the best indications of this is referred to in the statement quoted from Congressman Eckhardt's article. See note 9. supra. If public suits invariably or even more commonly than not "culminate" in an upholding of the public claim, then a rebuttable presumption of the existence of the public right is plainly rational.

37. It should be emphasized that, in approaching this question, the court would not be choosing its own allocation of the burden of proof (though it might well, in that case, choose the same one as section 205), but would, rather, be deciding whether the congressional allocation of this burden was intolerably irrational. 
presumption is not, of course, conclusive; the littoral owner who produces clear evidence of his right to exclude will doubtless prevail, leaving the Government either to abandon the matter or to condemn and pay for the public easement.

\section{Federal-State Framework}

The rest of the bill sets up a framework for federal-state cooperation, the constitutionality of which can scarcely be in doubt. ${ }^{38}$ In this regard it is worth noting that, besides deferring to state substantive law, the bill provides that beaches established as open as a result of suits brought under section 204 shall pass into the ownership and control of the state. ${ }^{39}$

\section{CONCLUSION}

In main outline, then, this bill seems to me past all doubt constitutional, both as to its assertion of a constitutionally based federal interest in the openness of the national beaches, and as to its bestowal of jurisdiction and authorization of public suits to vindicate public rights to this openness. Moreover, the creation of a rebuttable presumption in favor of public access and the establishment of a framework for federal-state cooperation are also well within Congress' constitutional powers. Finally, as a matter of public policy, I think it is a good and much-needed bill, but others have already made that case better than I can do. ${ }^{40}$

38. See Steward Mach. Co. v. Davis, 301 U.S. 548 (1937). part:

39. See H.R. 10394, $93 \mathrm{~d}$ Cong., 1st Sess. $\S 206$ (b) (1973), which states, in pertinent

All interests in land recovered under authority of this title shall be treated as subject to the ownership, control, and authority of the State in the same measure as if the State itself had acted to recover such interest. ...

For additional provisions outlining the scheme of federal-state cooperation see id. at \$ 206-10.

40. See note 9 supra. 